\title{
Effect of Weed Management in Yield Attributes of Manihot esculenta Crantz (Cassava)
}

\author{
S. Krishnaprabu* \\ Department of Agronomy, Faculty of Agriculture, Annamalai University, Annamalai Nagar, \\ Annamalai Nagar, Chidambaram 608 002, Tamil Nadu, India \\ *Corresponding author
}

\section{A B S T R A C T}

\begin{tabular}{|l|}
\hline Key word s \\
Cassava \\
Manihot esculenta \\
Tuber yield \\
Weed management \\
Weedicides
\end{tabular}

Weed management in farmer's cassava (Manihot esculenta Crantz) field was carried out during 2017 to assess the weed control and yield characteristics of cassava in eight different treatments (T1-T8) including weedy check which served as control. The treatments consisted of weedy check (control, T1), weed free (hand weeding as and when required, T2), pendimethalin@1.5 kg/ha (T3), pendiplus @ $1.50 \mathrm{~kg} / \mathrm{ha}$ (T4), imazethapyr @ 80g/ha (T5), pendimethalin@1.5 kg/ha + hoeing and earthing up (60 DAP) (T6), pendiplus @ $1.50 \mathrm{~kg} / \mathrm{ha}+$ hoeing and earthing up (60 DAP) (T7) and imazethapyr @ 80g/ha + hoeing and earthing up (60 DAP) (T8). The abundant weeds in the field were Boerhavia diffusa, Cyperus rotundus, Cyanodon dactylon, Phyllanthus maderaspatensis, Chloris barbata and Euphorbia hirta. The yield performance was higher in T2 followed by T6, T3, T8 and T7 where the tuber yield was 23759.46, 22758.17, 22408.53, 21284.60 and $20618.76 \mathrm{~kg} / \mathrm{ha}$ respectively.

\section{Introduction}

In tropical regions, cassava (Manihot esculenta Crantz) plays an important role in food security and poverty alleviation (Parkes et al., 2013). Cassava is rich in carbohydrates and sustainably contributes to nourish millions of people because of its availability over the year (Hongbété et al., 2011; Sanoussi et al., 2015). Many elite varieties have been identified and used worldwide (Gbessovi et al., 2016; Kombate et al., 2017). Weed management in agriculture is very important and difficult task for all kinds of crops (Dash et al., 2018; Kumar et al., 2018). The present scenario of high wages of labourers and also its scarcity particularly during peak periods and drudgery it seems to be imperative to go for chemical weed control due to its edge over manual weeding to overcome these problems (Singh et al., 2018). Aiyelari et al., (2017) concluded that although application of diuron at $2.25 \mathrm{~kg}$ a.i ha ${ }^{-1}$ gave the optimum weed control, it may be necessary to tank mix diuron at reduced rate with other compatible herbicides to broaden the spectrum of weed control.

Weed competition is one of the most important factors in limiting the yield of crops. 
The effective control of weeds in rice could be achieved with pre-emergence herbicide use of pretilachlor, penoxsulam and pyrazosulfuron. Among the post emergence herbicides use of chlorimuron-ethyl + metsulfuron-methyl, ethoxysulfuron, bispyribac sodium gives promising results (Kabdal et al., 2018). From this study, it could be concluded that under transplanted rice in sodic soil, pre emergence application of bensulfuron methyl + pretilachlor at $60+600 \mathrm{~g}$ a.i. $\mathrm{ha}^{-1}$ on 3 DAT fb hand weeding on 40 DAT resulted in increased yield attributes and nutrient uptake by rice. In cassava, it has been reported that weed control by hoe weeding and earthing up alone may increase the cost of production because of higher labour requirement. However, it was better to practice application of pre emergent herbicides like pendimethalin along with hoeing and earthing up at 60 DAP for effective weed control and reduction in cost of cultivation (Reshma et al., 2016). In the present study, the chemical weed control with pendimethalin, imazethapyr and pendiplus on pre-emergence application, hoeing and earthing up after 60 days have been studied to find out the different treatments on yield characteristics of cassava and weed control in farmer's field.

\section{Materials and Methods}

The experiment was carried out at the local farmer's field using the experimental design adopted was randomized block design (RBD) with eight treatments and three replications. The treatments consisted of weedy check (control, T1), weed free (hand weeding as and when required, T2), pendimethalin @ 1.5 kg/ha (T3), pendiplus @ 1.50 kg/ha (T4), imazethapyr @80g/ha (T5), pendimethalin@ $1.5 \mathrm{~kg} / \mathrm{ha}+$ hoeing and earthing up (60 DAP)(T6), pendiplus @ $1.50 \mathrm{~kg} / \mathrm{ha}+$ hoeing and earthing up (60 DAP) (T7) and imazethapyr @80g/ha + hoeing and earthing up (60 DAP) (T8). Vermicompost @6.5 t/ha was applied basally at the time of land preparation. Nitrogen, phosphate and potash @ 100:100:100 kg/ha was applied in three splits, at land preparation and two and three months after planting. The hoeing and earthing up was done 60 DAP. The crop was harvested after six months after planting and the yield characteristics and final weed numbers were counted and the data were subjected to analysis of variance (ANOVA). Benefit - cost ration (BCR) was worked out based on the prevailing market price.

\section{Results and Discussion}

The results on the yield characteristics of cassava in different treatments are shown in Table 1. The lowest yield of $11610.15 \mathrm{~kg} / \mathrm{ha}$ was recorded in T1. A maximum yield performance was found in T2 followed by T6, T3, T8 and T7 where the tuber yield was 23759.46, 22758.17, 22408.53, 21284.60 and $20618.76 \mathrm{~kg} / \mathrm{ha}$ respectively. The total number of tubers per plant was 8.72 in T2 followed by 8.21 in T7 which received pendiplus @ 1.50 $\mathrm{kg} / \mathrm{ha}+$ hoeing and earthing up (60 DAP). The length of the tuber was $45.91 \mathrm{~cm}$ in Weed free (Hand weeding as and when required, T2), followed by T7 [pendiplus@ $1.50 \mathrm{~kg} / \mathrm{ha}+$ hoeing and earthing up (60 DAP)]> 43.58 in T8 which received imazethapyr @ 80g/ha + hoeing and earthing up (60 DAP). The BCR ranged from $1.22-2.33$ in the treatments. The BCR was $1.22,1.73,2.03,1.82,1.80,2.33$, 1.93 and 2.23 respectively in $\mathrm{T} 1, \mathrm{~T} 2, \mathrm{~T} 3, \mathrm{~T} 4$, T5, T6, T7 and T8 respectively. The results showed that the hand weeding treatment had effective yield characteristics and very closely followed by pendimethalin@1.5 kg/ha with pre-emergence application (T3). The weed count at harvest showed greater reduction in the treatments T8 and T6 followed by other treatments (Fig. 1). 
Table.1 Effect of different treatments on yield characteristics of cassava and weed count

\begin{tabular}{|l|l|l|l|l|l|}
\hline \multicolumn{2}{|l|}{ Treatments } & $\begin{array}{l}\text { No. of } \\
\text { tubers/plant }\end{array}$ & $\begin{array}{l}\text { Length of } \\
\text { tuber }(\mathbf{c m})\end{array}$ & $\begin{array}{l}\text { Yield } \\
\text { (kg/ha) }\end{array}$ & BCR \\
\hline T1 & Weedy check (Control) & 4.56 & 23.82 & 11610.15 & 1.22 \\
\hline T2 & $\begin{array}{l}\text { Weed free (Hand weeding as and } \\
\text { when required) }\end{array}$ & 8.72 & 45.91 & 23759.46 & 1.73 \\
\hline T3 & Pendimethalin @ 1.5 kg/ha (PRE) & 7.60 & 39.02 & 22408.53 & 2.03 \\
\hline T4 & Pendiplus @ 1.50 kg/ha (PRE) & 6.89 & 35.67 & 19354.98 & 1.82 \\
\hline T5 & Imazethapyr @ 80g/ha (PRE) & 7.20 & 33.75 & 19762.39 & 1.80 \\
\hline T6 & $\begin{array}{l}\text { Pendimethalin @ 1.5 kg/ha + } \\
\text { Hoeing and earthing up (60 DAP) }\end{array}$ & 7.60 & 40.54 & 22758.17 & 2.33 \\
\hline T7 & $\begin{array}{l}\text { Pendiplus @ 1.50 kg/ha + Hoeing } \\
\text { and earthing up (60 DAP) }\end{array}$ & 8.21 & 45.61 & 20618.76 & 1.93 \\
\hline T8 & $\begin{array}{l}\text { Imazethapyr @ 80g/ha + Hoeing } \\
\text { and earthing up (60 DAP) }\end{array}$ & 7.90 & 43.58 & 21284.60 & 2.23 \\
\hline
\end{tabular}

Table.2 Commonly found weeds of cassava field

\begin{tabular}{|c|l|l|}
\hline Sl. No. & Name of the weed & Family \\
\hline $\mathbf{1 .}$ & Almania nodiflora & Amaranthaceae \\
\hline $\mathbf{2 .}$ & Alternanthera pungens & Amaranthaceae \\
\hline $\mathbf{3 .}$ & Boerhaavia diffusa & Nyctaginaceae \\
\hline $\mathbf{4 .}$ & Cenchrus ciliaris & Poaceae \\
\hline $\mathbf{5 .}$ & Chloris barbata & Poaceae \\
\hline $\mathbf{6 .}$ & Cyanodon dactylon & Poaceae \\
\hline $\mathbf{7 .}$ & Cyperus rotundus & Cyperaceae \\
\hline $\mathbf{8 .}$ & Dactyloctenium aegypticum & Poaceae \\
\hline $\mathbf{9 .}$ & Digera muricata & Amaranthaceae \\
\hline $\mathbf{1 0 .}$ & Euphorbia hirta & Euphorbiaceae \\
\hline $\mathbf{1 1}$. & Glinus lotoides & Molluginaceae \\
\hline $\mathbf{1 2 .}$ & Oldenlandia corymbosa & Rubiaceae \\
\hline $\mathbf{1 3}$. & Phyllanthus amarus & Euphorbiaceae \\
\hline $\mathbf{1 4}$. & Phyllanthus maderaspatensis & Euphorbiaceae \\
\hline $\mathbf{1 5}$. & Portulaca oleraceae & Portulaccaceae \\
\hline $\mathbf{1 6}$ & Spermacoce hispida & Rubiaceae \\
\hline $\mathbf{1 7}$ & Trianthema portulacastrum & Aizoaceae \\
\hline $\mathbf{1 8}$. & Tribulus terrestris & Zygophyllaceae \\
\hline $\mathbf{1 9}$ & Trichodesma indicum & Boraginaceae \\
\hline $\mathbf{2 0}$ & Tridax procumbens & Asteraceae \\
\hline & & \\
\hline
\end{tabular}


Fig.1 Weed count at harvest of cassava in different treatments. Error bars indicate standar deviation. Trend line shows the decline in number of weeds in comparison with weed check control

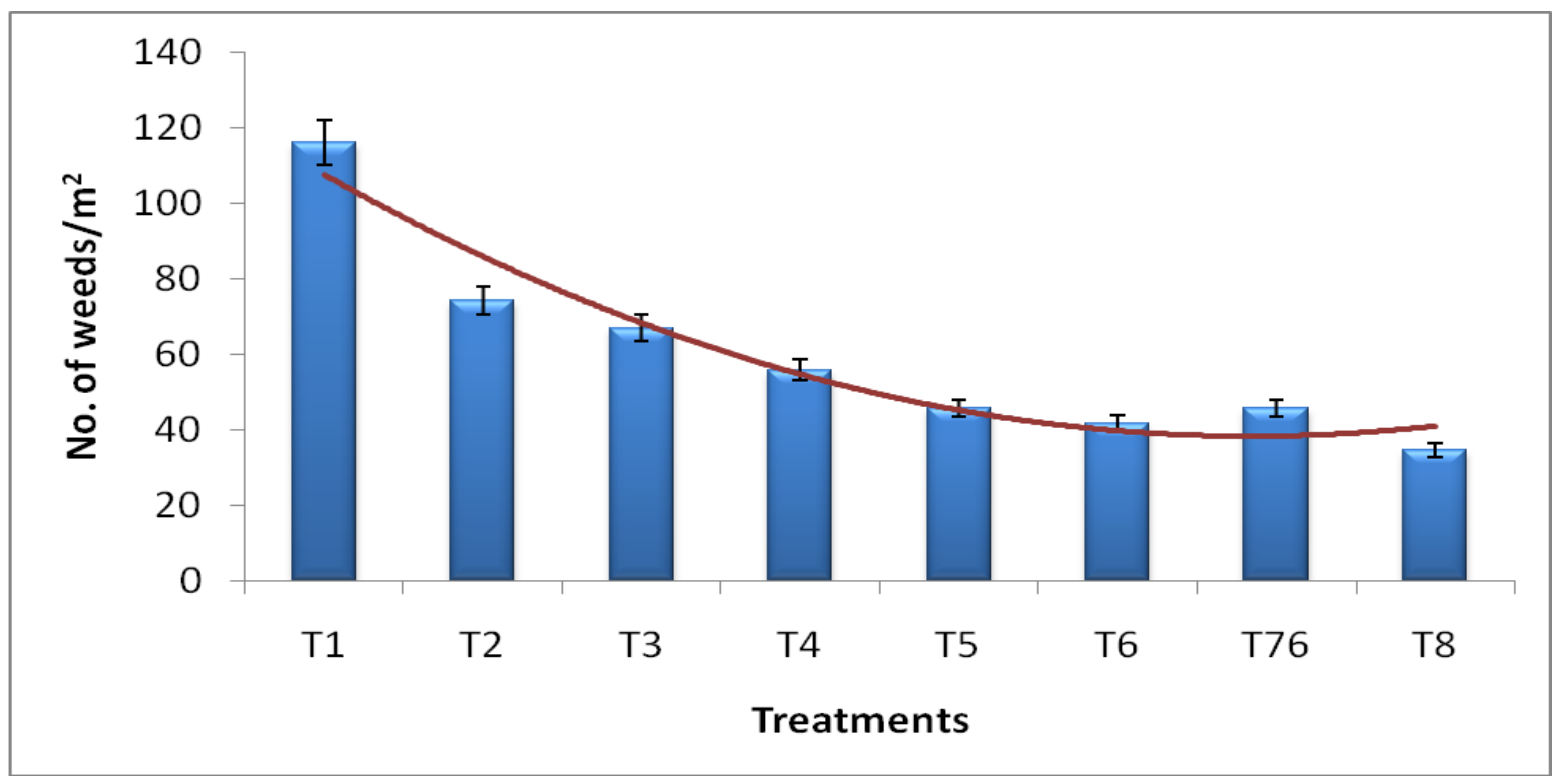

There were more than twenty weeds commonly found in the study plots which were Almania nodiflora (Amaranthaceae), Alternanthera pungens (Amaranthaceae), Boerhaavia diffusa (Nyctaginaceae), Cenchrus ciliaris (Poaceae), Chloris barbata (Poaceae), Cyanodon dactylon (Poaceae), Cyperus rotundus (Cyperaceae), Dactyloctenium aegypticum (Poaceae), Digera muricata (Amaranthaceae), Euphorbia hirta (Euphorbiaceae), Glinus lotoides (Molluginaceae), Oldenlandia corymbosa (Rubiaceae), Phyllanthus amarus (Euphorbiaceae), Phyllanthus maderaspatensis (Euphorbiaceae), Portulaca oleraceae (Portulaccaceae), Spermacoce hispida (Rubiaceae), Trianthema portulacastrum (Aizoaceae), Tribulus terrestris (Zygophyllaceae), Trichodesma indicum (Boraginaceae) and Tridax procumbens (Asteraceae) (Table 2). The studies by other researchers also showed similar results. Kabdal et al., (2018) reported that thehe effective control of weeds in rice could be achieved with pre-emergence herbicide use of pretilachlor, penoxsulam and pyrazosulfuron. Under transplanted rice in sodic soil, pre emergence application of bensulfuron methyl + pretilachlor at $60+600$ $\mathrm{g}$ a.i. $\mathrm{ha}^{-1}$ on 3 DAT fb hand weeding on 40 DAT resulted in increased yield attributes and nutrient uptake by rice. In cassava, it has been reported that weed control by hoe weeding and earthing up alone may increase the cost of production because of higher labour requirement. However, it was better to practice application of pre emergent herbicides like pendimethalin along with hoeing and earthing up at 60 DAP for effective weed control and reduction in cost of cultivation (Reshma et al., 2016). So, better integration of chemical control along with other farming management practices may provide further improvement in weed management in cassava field.

\section{References}

Aiyelari O. P., Aiyelari, A. O. E., Aladesanwa, R. D., Agele, S. O., 2017. Evaluation of diuron for post emergence weed control in pineapples [Ananas 
comosus (L). Merr]. Int. J. Curr. Res. Biosci. Plant Biol. 4(12), 30-34.

Dash, M., Tandon, M., Mohapatra, S., 2018. A review on integrated weed management in green gram. Int. J. Curr. Microbiol. App. Sci. 7(6), 1865-1871.

Gbessovi, D. R., Agre, P., Sanoussi, A. F., Dassou, A., Dansi, A., Adjatin, A., Dansi, M., Ahissou, H., 2016. Physicochemical characteristics and suitability for selected local foods of the elite cassava (Manihot esculenta Crantz) cultivars of central Benin. Int. J. Curr. Res. Biosci. Plant Biol. 3(3), 3947.

Kabdal, P., Tej Pratap, Yadav, V. R., 2018. Weed management in transplanted riceA review. Int. J. Curr. Microbiol. App. Sci. 7(4), 1660-1669.

Kombate, K., Dansi, A., Dossou-Aminon, I., Adjatin, A., Kpemoua, K., Dansi, M., Akpagana, K., Sanni, A., 2017. Diversity of cassava (Manihot esculenta Crantz) cultivars in the traditional agriculture of Togo. Int. J. Curr. Res. Biosci. Plant Biol. 4(6), 98-113.

Kumar, S., Pandey, N., Kumar, A., Singh, A. K., Gopal, T., Kumar, D., 2018. Effect of establishment methods and weed management practices on economics of direct seeded rice (Oryza sativa L.). Int.
J. Curr. Microbiol. App. Sci. 7(4), 14731480.

Parkes, E.Y., Fregene, M., Dixon, A., Boakye-Peprah, B., Labuschagne, M.T., 2013. Combining ability of cassava genotypes for cassava mosaic disease and cassava bacterial blight, yield and its related components in two ecological zones in Ghana. Euphytica. 194, 13-24.

Reshma, N., Sindhu, P.V., George Thomas, C., Menon, M. V., 2016. Integrated weed management in cassava (Manihot esculenta Crantz). J. Root Crops. 42(1), 22-27.

Sanoussi, A. F., Loko, L. Y., Ahissou, H., Adjahi, A. K., Orobiyi, A., Agré, A. P., Azokpota, P., Dansi, A., Sanni, A., 2015. Diversity, physicochemical and technological characterization of elite cassava (Manihot esculenta Crantz) cultivars of Bantè, a district of central Benin. Scient. World J. 2015(2015), Article ID 674201, 8 pages.

Singh, R. S., Narayan, A., Singh, P. P., 2018. Effect of weed management practices on weed dynamics, yield and economics of elephant foot yam (Amorphophallus paeoniifolious). Int. J. Curr. Microbiol. App. Sci. (Special Issue) 7, 4592-4598.

\section{How to cite this article:}

Kashish Walia, R.K. Aggrawal and Bhardwaj, S.K. 2019. Evaluation of Air Pollution Tolerance Index and Anticipated Performance Index of Plants and their Role in Development of Green Belt along National Highway-22. Int.J.Curr.Microbiol.App.Sci. 8(03): 2514-2518. doi: https://doi.org/10.20546/ijcmas.2019.803.298 